\title{
Medical Journal Publishing: Continued struggle is essential to Achieve and maintain standards
}

\author{
Shaukat Ali Jawaid
}

doi: https://doi.org/10.12669/pjms.36.4.2685

How to cite this:

Jawaid SA. Medical Journal Publishing: Continued struggle is essential to Achieve and maintain standards. Pak J Med Sci. 2020;36(4):848-852. doi: https://doi.org/10.12669/pjms.36.4.2685

This is an Open Access article distributed under the terms of the Creative Commons Attribution License (http://creativecommons.org/licenses/by/3.0), which permits unrestricted use, distribution, and reproduction in any medium, provided the original work is properly cited.

During the Year 2019, Pakistan Journal of Medical Sciences received a total of one thousand four hundred nineteen manuscripts. Out of this, three hundred twenty five were published, nine were rejected due to plagiarism, thirty one were withdrawn by the authors as they were keen to get it published immediately while the remaining were not accepted for further processing during initial screening for various reasons. Table-I. During the same period thirty manuscripts were accepted for fast track processing, twenty five such requests were rejected. Fast track processing facility was started to help those authors who either had to appear in some examination or had to submit their Thesis for $\mathrm{PhD}$ or M. Phil and it was essential to get a paper published before that. However, it was also observed that an attempt was made by some authors to misuse this facility as their promotion was due or they just wanted to get their manuscripts published early. Since our objective is to help facilitate authors to publish their research work and not to make money, as a policy it was decided that those who wish to get their papers processed on fast track must first ask for permission, specify the reasons and if accepted only then they should opt for this and arrange fast track processing fee. The idea was to discourage authors to make use of this facility unless it was extremely essential. We do Publication Audit regularly every year as it helps to identify the strength and weaknesses that is very helpful in improving the contents as well as standard of the journal. ${ }^{1-3}$

Correspondence:

Shaukat Ali Jawaid

Chief Editor,

Pakistan Journal of Medical Sciences,

Karachi - Pakistan.

E-mail: pulse@pulsepakistan.com pjms@pjms.org.pk
Yet another policy decision taken was that if the authors had any doubt about acceptance of their paper for further processing, they were asked to first share the abstract of their manuscript by e-mail and get an opinion whether we can process their manuscript or not and if they get a positive response, only then complete the other formalities of submission on the journal website with all the necessary documents like Letter of Undertaking of exclusive submission and Ethics Committee approval besides arranging processing fee. It not only helped the authors to save their money but also saved the time of the editorial team to reduce the number of submissions on the website for initial screening and further processing. That is one of the reasons that the graph of submission during the Year 2019 shows a little downward trend. Fig.1.

A detailed analysis of the submissions during the Year under review also showed that as usual more submissions from overseas were from countries like Turkey, China, and Saudi Arabia i.e. Three

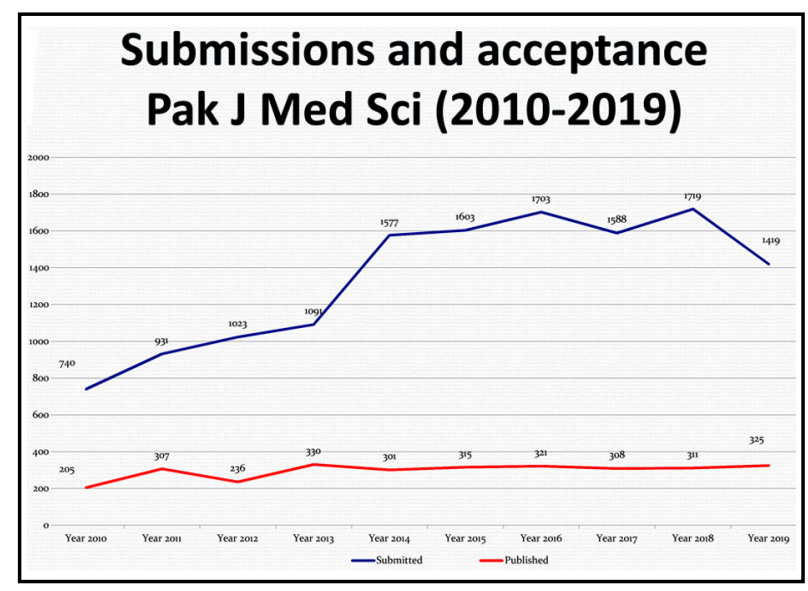

Fig.1

$\begin{array}{lllll}\text { Pak J Med Sci } \quad \text { May - June } 2020 & \text { Vol. } 36 & \text { No. } 4 \quad \text { www.pjms.org.pk } 848\end{array}$ 
Table-I: PJMS manuscripts statistics of 2019 at a Glance.

\begin{tabular}{ll}
\hline Total Published Articles: & 325 \\
Total Rejected Articles: & 981 \\
Total rejected article on plagiarism: & 9 \\
Total Withdraw Articles: & 31 \\
Under Process: & 73 \\
Total Received Articles: & 1419 \\
\hline
\end{tabular}

hundred thirty four, one hundred forty seven and one hundred thirty eight respectively. Table-II. Over the years the number of submissions from China, Iran has drastically reduced simply because we are more careful, selected only good quality manuscripts besides encouraging the authors to publish their manuscripts in their local journals. As such the number of manuscripts published from these countries since 2010-2019 has varied. Table-III.

Total number of papers received from Pakistan during the Year 2019 was five hundred fifty nine while the number of papers published from Pakistan was one hundred sixty eight. Over the years there has been a progressive increase in the number of papers published from Pakistan because we wish to encourage more Pakistani authors to publish in local journals. While in the past the percentage of papers from Pakistan in each issue of Pakistan Journal of Medical Sciences used to just about $20 \%$, now it has increased to almost $50 \%$. We have also observed an appreciable improvement in the quality of manuscripts that we attract from the authors from Pakistan as well. Table-IV. As expected the largest number of manuscript published during the Year 2019 were original articles. Table-V. A further analysis of submission from Pakistan revealed that maximum number of manuscripts was submitted from Karachi followed by Lahore, Peshawar and Rawalpindi despite the fact that a large number of medical journals are also published from these cities but it is also a fact that more research work is also undertaken in these cities for various reasons. Table-VI. However, it was heartening to note that the journal attracted manuscripts from many small cities from all over the country as well which is a witness of increasing readership and popularity of the journal among the healthcare professionals.

Since the objective of the Journal and its Editorial team is not just to accept, reject and publish papers but also teach and train the authors, Editorial team of Pakistan Journal of Medical Sciences has been actively participating in organizing as well
Table-II: Country wise submissions during 2019.

\begin{tabular}{|c|c|}
\hline Country & Total \\
\hline Afghanistan & 2 \\
\hline Albania & 1 \\
\hline Algeria & 1 \\
\hline Antarctica & 1 \\
\hline Argentina & 1 \\
\hline Armenia & 1 \\
\hline Australia & 1 \\
\hline Azerbaijan & 1 \\
\hline Bangladesh & 1 \\
\hline Brazil & 2 \\
\hline China & 147 \\
\hline Christmas Island & 2 \\
\hline Cyprus & 4 \\
\hline Egypt & 10 \\
\hline India & 7 \\
\hline Indonesia & 55 \\
\hline Iran & 53 \\
\hline Iraq & 30 \\
\hline Italy & 2 \\
\hline Jordan & 4 \\
\hline Korea & 9 \\
\hline Malaysia & 14 \\
\hline Nigeria & 10 \\
\hline Pakistan & 559 \\
\hline Palestinian & 2 \\
\hline Pitcairn & 1 \\
\hline Romania & 2 \\
\hline Russia & 2 \\
\hline Rwanda & 1 \\
\hline Saint Barthelemy & 2 \\
\hline Saudi Arabia & 138 \\
\hline Singapore & 2 \\
\hline Swaziland & 1 \\
\hline Thailand & 1 \\
\hline Turkey & 334 \\
\hline Ukraine & 1 \\
\hline United Arab Emirates & 1 \\
\hline United Kingdom & 5 \\
\hline United States & 5 \\
\hline Viet Nam & 3 \\
\hline Grand Total & 1419 \\
\hline
\end{tabular}

as facilitating workshop on Scientific Writing, Peer Review and training courses on Journal publishing not only in Pakistan but in the EMRO region as well. ${ }^{4}$ Such academic activities were organized in Riyadh Saudi Arabia, Gulf countries as well in addition to pre-conference workshops at various medical institutions in collaboration with different professional specialty organizations. However, still there is lot of pressure from the authors and those whose manuscripts are not 
Table-III: Manuscript published by Pak J Med Sci (2010 - 2019).

\begin{tabular}{|c|c|c|c|c|c|c|c|c|c|c|}
\hline Country & 2010 & 2011 & 2012 & 2013 & 2014 & 2015 & 2016 & 2017 & 2018 & 2019 \\
\hline Algeria & & & & & & & 1 & & & 1 \\
\hline Australia & & & & & & & 1 & 1 & 1 & 1 \\
\hline Bahrain & 1 & & & 1 & 1 & & & & & \\
\hline Bangladesh & 4 & 4 & 4 & & 1 & 1 & 1 & & 1 & \\
\hline Cameroon & 1 & & & & & & & & & \\
\hline China & 1 & 18 & 34 & 80 & 89 & 65 & 66 & 54 & 43 & 46 \\
\hline Cyprus & & & 1 & 1 & & & & & 3 & 1 \\
\hline Fiji & & & & & & 1 & & & & \\
\hline Germany & & & & 1 & & & & & & \\
\hline India & 2 & 1 & & 1 & & 1 & 1 & & 1 & 1 \\
\hline Iran & 64 & 78 & 63 & 70 & 14 & 12 & 11 & 10 & 3 & 8 \\
\hline Iraq & 1 & 3 & 2 & 3 & 1 & & 1 & & 2 & 3 \\
\hline Japan & & & & & & & & 1 & & \\
\hline Jordan & 4 & & 1 & & & & & & & 1 \\
\hline Kenya & & & 1 & & & & & & & \\
\hline Korea & 1 & 2 & 1 & 3 & 2 & 5 & 7 & 2 & 2 & 1 \\
\hline Kuwait & 1 & & 1 & & & & & & & \\
\hline Malaysia & 1 & 9 & 3 & 9 & 7 & 10 & 6 & 1 & 1 & \\
\hline Nigeria & 10 & 9 & & & 4 & 4 & 1 & & & \\
\hline Oman & 1 & & 1 & & & 1 & & & & \\
\hline Pakistan & 56 & 93 & 65 & 91 & 93 & 106 & 135 & 163 & 150 & 168 \\
\hline Palestine & 2 & & & 3 & 1 & 2 & & & & \\
\hline Philippines & & & & & & & 1 & & & \\
\hline Poland & & & & & 2 & 4 & & & & \\
\hline Romania & & & & 1 & 1 & 3 & 1 & 1 & 1 & \\
\hline Saudi Arabia & 11 & 6 & 16 & 17 & 19 & 32 & 23 & 21 & 24 & 32 \\
\hline Serbia & & & & & & & & 1 & 1 & 1 \\
\hline South Africa & 3 & 2 & 1 & 6 & 2 & & 1 & & & \\
\hline Sudan & 1 & & & & & & & & & \\
\hline Taiwan & & 2 & 2 & 3 & & & & & & \\
\hline Thailand & & & & & & & & & 2 & \\
\hline Turkey & 34 & 74 & 37 & 38 & 60 & 65 & 63 & 49 & 72 & 60 \\
\hline UAE & 4 & 1 & 1 & & & 2 & & 1 & 3 & \\
\hline Uganda & & & 1 & & & & & & & \\
\hline UK & 2 & 5 & 1 & 2 & & 1 & 1 & 1 & 1 & 1 \\
\hline USA & & & & & 4 & & & 2 & & \\
\hline Total (36) & 205 & 307 & 236 & 330 & 301 & 315 & 321 & 308 & 311 & 325 \\
\hline
\end{tabular}

accepted for further processing or publication are not happy. It is this strict policy and peer review system that has helped us to retain the highest Impact Factor among the Pakistani biomedical journals for the last many years. Fig.2. However, the authors must realize that we have our own financial as well as human resource constraints. Hence, even if we entertain more manuscripts for further processing, it will take too long to get them published and the authors will have to wait much longer which they will neither like nor it will be in their interest. Hence, it is better if they submit their manuscripts to those journals which can process them early. Every author is keen to get their research work published as soon as possible

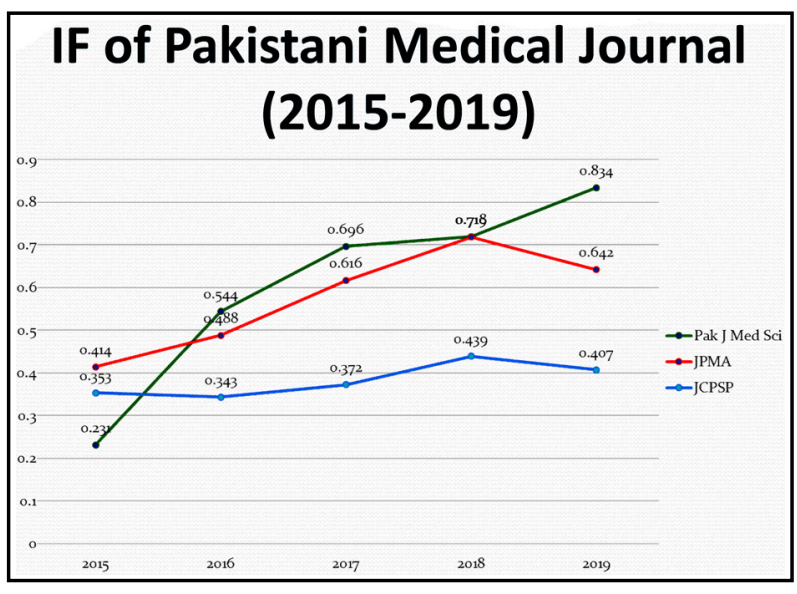

Fig.2 
Table-IV: Country Wise Manuscript Published in 2019.

\begin{tabular}{lccccccc}
\hline Country & $\begin{array}{c}\text { Jan-Feb } \\
\text { 2019 }\end{array}$ & $\begin{array}{c}\text { Mar-April } \\
2019\end{array}$ & $\begin{array}{c}\text { May-June } \\
2019\end{array}$ & $\begin{array}{c}\text { July-Aug } \\
2019\end{array}$ & $\begin{array}{c}\text { Sep-Oct } \\
2019\end{array}$ & $\begin{array}{c}\text { Nov-Dec } \\
2019\end{array}$ & $\begin{array}{c}\text { Grand } \\
\text { Total }\end{array}$ \\
\hline Algeria & -- & -- & -- & -- & 1 & -- & 1 \\
Australia & -- & -- & -- & -- & 1 & -- & 1 \\
China & - & 8 & 9 & 6 & 10 & 5 & 46 \\
Cyprus & -- & -- & 1 & -- & -- & -- & 1 \\
India & -- & -- & 1 & -- & -- & -- & 1 \\
Iran & 1 & 2 & 2 & 1 & 1 & 1 & 8 \\
Iraq & -- & -- & -- & 2 & 1 & -- & 3 \\
Jordan & -- & -- & -- & -- & -- & 1 & 1 \\
Korea & -- & 1 & -- & -- & - & -- & 1 \\
Pakistan & 31 & 26 & 23 & 28 & 31 & 29 & 168 \\
Saudi Arabia & 2 & 4 & 9 & 9 & 1 & 7 & 32 \\
Serbia & -- & -- & -- & 1 & -- & -- & 1 \\
Turkey & 13 & 13 & 9 & 8 & 8 & 9 & 60 \\
United Kingdom & -- & -- & 1 & -- & -- & -- & 1 \\
\hline Grand Total & 55 & 54 & 55 & 55 & 54 & 52 & 325 \\
\hline
\end{tabular}

but at times it is not possible. The solution lies in having more and more good quality peer reviewed biomedical journals.

Keeping the above in view, Pakistan Journal of Medical Sciences as a member of PAME in collaboration with some other distinguished editors has initiated a Certificate Course in Medical Editing at University of Health Sciences at Lahore. It is a joint project of PAME with UHS in which we have the support of many distinguished researchers and editors from Pakistan as well as overseas who have agreed to help and mentor these course candidates. Sixty candidates applied for the first course out of which thirty were selected, preference being given to those who were already affiliated with some journal. The first batch has completed the course and their final portfolio assessment and Viva Exam was scheduled on
March $16^{\text {th }} 2020$ which had to be postponed due to COVID19. We hope to organize this as soon as the situation improves and arrangement will be made to induct the second batch hopefully before August 2020. ${ }^{5}$

Yet another decision we have taken is to publish two special issues every year exclusively of Case Reports. Though they usually have a low priority with us but many authors are keen to get their case reports published and it is also the ideal way to start publishing for many young authors. These issues will be only Online Publications and no print copies will be available. However, they will go through the routine initial screening, plagiarism check, peer review, will have DOI number and they will also be visible online through PubMed Central. Publication of some other special issues, thematic issues will also

Table-V: Category Wise Manuscript Published in 2019.

\begin{tabular}{lccccccc}
\hline Category & $\begin{array}{c}\text { Jan-Feb } \\
\text { 2019 }\end{array}$ & $\begin{array}{c}\text { Mar-Apr } \\
2019\end{array}$ & $\begin{array}{c}\text { May-Jun } \\
\text { 2019 }\end{array}$ & $\begin{array}{c}\text { Jul-Aug } \\
2019\end{array}$ & $\begin{array}{c}\text { Sep-Oct } \\
2019\end{array}$ & $\begin{array}{c}\text { Nov-Dec } \\
2019\end{array}$ & $\begin{array}{c}\text { Grand } \\
\text { Total }\end{array}$ \\
\hline Case Reports & -- & 2 & 1 & -- & 1 & 2 & 6 \\
Conference Proceedings & -- & -- & -- & -- & - & 1 & 1 \\
Correspondence & -- & -- & 1 & & 1 & 1 & 3 \\
Editorial & 1 & -- & -- & 2 & -- & -- & 3 \\
Guest Editorial & -- & -- & 1 & & -- & -- & 1 \\
Original Articles & 52 & 48 & 51 & 51 & 51 & 46 & 299 \\
Review Article & 1 & -- & -- & 1 & -- & 1 & 3 \\
Short Communication & 1 & 1 & -- & -- & -- & 1 & 3 \\
Special Communication & -- & -- & 1 & -- & -- & - & 1 \\
Systematic Review & -- & 3 & -- & 1 & 1 & -- & 5 \\
\hline Grand Total & 55 & 54 & 55 & 55 & 54 & 52 & 325 \\
\hline
\end{tabular}


Table-VI: City wise submissions from Pakistan during 2019.

\begin{tabular}{|c|c|}
\hline Cities & Total \\
\hline Abbottabad & 1 \\
\hline Azad Kashmir & 1 \\
\hline Bahawalpur & 4 \\
\hline Chitral & 1 \\
\hline D.I. Khan & 1 \\
\hline Faisalabad & 11 \\
\hline Gambt, Khairpur, Sindh & 1 \\
\hline Gilgit & 3 \\
\hline Gujranwala & 4 \\
\hline Gujrat & 10 \\
\hline Haripur & 1 \\
\hline Hyderabad & 6 \\
\hline Islamabad & 59 \\
\hline Jamshoro & 5 \\
\hline Karachi & 207 \\
\hline Karak & 1 \\
\hline Kasur & 1 \\
\hline Khairpur Mirs, Sindh & 1 \\
\hline Kharian Cantt. & 1 \\
\hline Kohat & 1 \\
\hline Lahore & 112 \\
\hline Larkana & 1 \\
\hline Mansehra & 1 \\
\hline Mardan & 1 \\
\hline Mirpurkhas & 1 \\
\hline Multan & 11 \\
\hline Muzaffarabad & 1 \\
\hline Nawabshah & 2 \\
\hline Peshawar & 42 \\
\hline Poonch, Azad Kashmir & 2 \\
\hline Quetta & 10 \\
\hline Rabwah, Punjab & 1 \\
\hline Rahim Yar Khan & 3 \\
\hline Raiwind, Punjab & 1 \\
\hline Rawalakot, Azad Kashmir & 2 \\
\hline Rawalpindi & 26 \\
\hline Sargodha & 5 \\
\hline Sialkot & 5 \\
\hline Sukkur & 1 \\
\hline Swat & 2 \\
\hline Tando M. Khan & 2 \\
\hline Wazirabad & 1 \\
\hline Dera Ghazi Khan & 3 \\
\hline Mirpur, Azad Kashmir & 1 \\
\hline Shikarpur & 1 \\
\hline Dera Ismail Khan & 1 \\
\hline Grand Total & 559 \\
\hline
\end{tabular}

be considered. In view of the current COVID19 Pandemic, a special issue on Corona Virus has also been planned which will be published in the next two months. Submissions in this issue have been processed on fast track on complimentary basis just to help authors.

In short every effort is being made to help authors by following an author friendly policy to promote research culture, the art of medical writing and scientific publishing in the country. Numerous informative manuscripts which provide details about the manuscript processing system, peer review policy, guidelines for the authors following which they can minimize trauma to their submitted manuscripts are published from time to time all aimed at helping the authors. ${ }^{6-7}$ However, it is extremely difficult to please everyone and our experience also shows that those who are more impatient and keen to get their manuscripts processed on fast track, the quality of most of these manuscripts is not so good. In a hurry, these authors even do not bother to carefully read and follow the instructions for authors on journal website which leads to enormous delay in processing of their manuscripts. It is in their own interest to read and follow these instructions in letter and spirit and also look at some of the published papers on our website before making their submissions.

\section{REFERENCES}

1. Jawaid SA. Need to have more Biomedical Journals with Impact Factor and importance of Publication Audit. Pak J Med Sci. 2019;35(4):882-886. doi: https://doi.org/10.12669/ pjms.35.4.1300

2. Jawaid SA. Importance of Publication Audit, fast track processing and categorization of manuscripts. Pak J Med Sci. 2017;33(2):513-516. doi: https://doi.org/10.12669/ pjms.332.12858

3. Jawaid SA. Publication Audit - a useful tool to evaluate progress and plan for the future. Pak J Med Sci 2015;31(2):490492. doi: http://dx.doi.org/10.12669/pjms.312.7682

4. Jawaid SA. Proceedings of Workshop on Scientific Writing and Publishing organized by EMAME-DHA at Dubai (June 22-24th 2018). Pak J Med Sci. 2018;34(4):1034-1042. doi: https://doi.org/10.12669/pjms.344.16084

5. Jawaid SA, Jawaid M. Professional capacity building of Health Science Journal Editors. Pak J Med Sci. 2019;35(4):879881. doi: https://doi.org/10.12669/pjms.35.4.1299

6. Jawaid SA, Jawaid M. Common reasons for not accepting manuscripts for further processing after editor's triage and initial screening. Pak J Med Sci. 2019;35(1):1-3. doi: https:// doi.org/10.12669/pjms.35.1.28.

7. Jawaid SA, Jawaid M. Author's failure to read and follow instructions leads to increased trauma to their manuscripts. Pak J Med Sci. 2018;34(3):519-524. doi: https://doi. org/10.12669/pjms.343.15633 